\title{
Historia polskiej płacy minimalnej na gruncie teorii pomiaru kapitału ludzkiego i godziwych wynagrodzeń ${ }^{2}$
}

\section{WSTĘP}

Płaca minimalna to jedna ze spornych kwestii ekonomicznych. Minimalne wynagrodzenie jest z jednej strony zabezpieczeniem pracowników przed wyzyskiem ze strony pracodawcy, $\mathrm{z}$ drugiej strony natomiast może być przeszkodą w zwalczaniu bezrobocia. Zgodnie z ustawą o minimalnym wynagrodzeniu (Ustawa, 2002) płaca minimalna to wynagrodzenie, które powinien otrzymać pracownik zatrudniony w pełnym wymiarze czasu pracy, wykonujaccy najprostsze prace.

Artykuł ma na celu przedstawienie historii płacy minimalnej w Polsce od początku jej istnienia oraz zbadanie jej zgodności z wartością kapitału ludzkiego wyznaczoną na podstawie współczesnej teorii pomiaru kapitału ludzkiego i godziwych wynagrodzeń. W pierwszej części opracowania przedstawiona jest historia polskiej płacy minimalnej oraz współczesne poglądy w kwestii kapitału ludzkiego i godziwych wynagrodzeń. W dalszej części zbadana została godziwość polskiej płacy minimalnej. Do realizacji celu wykorzystano metodę analityczno-opisową. Narzędziem empirycznym służącym weryfikacji były studia literatury przedmiotu oraz studia i analiza danych statystycznych.

Godziwość polskiej płacy minimalnej zbadano z wykorzystaniem modelu płacy godziwej $W$ wynikającego z ogólnego modelu kapitału ludzkiego. Zgodnie z naturą kapitału, losowe rozproszenie kapitału ludzkiego, wynika z istoty życia i powinno być równoważone godziwym wynagrodzeniem pracownika. Płaca godziwa daje możliwość pracownikowi zaspokoić niezbędne potrzeby, jak również pomaga odtworzyć kapitał ludzki w długim okresie dzięki wychowaniu i wykształceniu swoich potomków.

${ }^{1}$ Adres do korespondencji: e-mail: boliwkiewicz@afm.edu.pl. ORCID: 0000-0002-0752-2288.

${ }^{2}$ Artykuł dofinansowano ze środków przeznaczonych na działalność statutową Wydziału Zarządzania i Komunikacji Społecznej Krakowskiej Akademii im. A. F. Modrzewskiego nr WZiKS/DS/3/ 2017-KON. 


\section{WSPÓŁCZESNA TEORIA POMIARU KAPITALU LUDZKIEGO}

Badania w zakresie kapitału ludzkiego prowadzone są wieloma drogami. Główna droga to teorie G. Beckera (Becker, 1975) i jego następców, np. J. Mincera (Mincer, 1962) i innych. G. Becker zajmował się głównie badaniem stopy zwrotu nakładów na kształcenie natomiast J. Mincer i inni stosują modelowanie ekonometryczne. M. Blaug (Blaug, 1995, s. 320) pisał: „Proces degeneracji programu badawczego poświęconemu kapitałowi ludzkiemu trwał w latach osiemdziesiątych. Uprawiający go teoretycy w nieskończoność przeżuwali stary materiał, co w żaden sposób nie przyczyniało się do rzucenia nowego światła na kwestie kształcenia i szkolenia zawodowego." Inne podejście do badań nad kapitałem ludzkim, jako odrębny Naukowy Program Badawczy, zostało zaproponowane na początku lat 90. ubiegłego stulecia przez M. Dobiję i innych (Dobija, 2010, 2011, 2014).

Badania przeprowadzone $\mathrm{w}$ świetle współczesnej teorii pomiaru kapitału ludzkiego i godziwych wynagrodzeń dotyczą problematyki stopy procentowej, jako ekonomicznej wielkości bazowej sterującej procesami gospodarczymi w skali mikro i makroekonomicznej. W trakcie badań wyjaśniono naturę kapitału i dowiedziono istnienie stałej ekonomicznej potencjalnego wzrostu $p$ (SEPW), którą uznano za tempo pomnażania kapitału.

Główne tezy współczesnej teorii kapitału ludzkiego i godziwych wynagrodzeń to poprawne zrozumienie natury kapitału, potraktowanie kapitału ludzkiego, jako potencjalnej zdolności do wykonywania pracy, pracy, jako transferu kapitału ludzkiego do obiektów pracy i płacy, jako należności za wykonaną pracę. Udowodniono, że zasady opłacenia kapitału ludzkiego wynikają z natury kapitału. Dowiedziono także, że nikt nie może stworzyć kapitału ludzkiego jak również, że sam kapitał nie powstaje z niczego. Można wskazać jego źródła i możliwa jest jego wycena w jednostkach pieniężnych. Człowiek gromadzi w swoim organizmie kapitał ludzki od momentu narodzin. Niestety, w związku z wykonywaniem pracy, chorobami i innymi zdarzeniami losowymi kapitał ludzki ulega rozproszeniu. Ubytki te powinny być rekompensowane przez godziwe wynagrodzenie. Przy ustalaniu wysokości godziwego wynagrodzenia należy zastosować stałą ekonomiczną potencjalnego wzrostu $p$ (SEPW), która jest wynikiem wpływu Natury na wzrost ekonomiczny (Dobija, 2016, s. 33). Badania poprzedników potwierdzają rozmiar stałej, SEPW jako $p=8 \%$ w skali roku (Kurek, 2011; Kozioł, 2011; Renkas, 2012).

Model płacy godziwej $W$ wykorzystywany do obliczeń w niniejszym opracowaniu wynika z ogólnego modelu kapitału ludzkiego (Dobija, 2009):

$$
C_{\mathrm{t}}=C_{0} \times e^{(\mathrm{p}-\mathrm{s}+\mathrm{m}) \mathrm{t}}, p=E(s)=0,08[1 / \mathrm{rok}]
$$

gdzie: $C_{\mathrm{t}}$ - kapitał końcowy; $C_{0}-$ kapitał początkowy; $e$ - liczba Eulera; $p$ - stała ekonomiczna potencjalnego wzrostu (SEPW); $s$ - tempo naturalnego, spontanicz- 
nego rozpraszania kapitału; $m$ - tempo przyrostu kapitału w skutek wykonywanej pracy; $t$ - zmienna upływu czasu

Prawa strona równania (1) przedstawia kapitał początkowy, który zgodnie z pierwszą zasadą termodynamiki, nie powstaje z niczego. Jedynie już zgromadzony kapitał może się zmniejszyć poprzez spontaniczne rozpraszanie lub zwiększyć poprzez osiąganie przychodów ze źródeł naturalnych oraz pracy. Przykładem, który ilustruje te stwierdzenia, jest człowiek i jego kapitał ludzki. Noworodek w momencie narodzin posiada już swój kapitał początkowy $\left(C_{0}\right)$, który bez zainteresowania rodziców uległby rozproszeniu $\left(e^{-s t}\right)$ i doprowadził do śmierci niemowlaka. Nakłady rodziców i działania społeczeństwa niwelują proces rozproszenia kapitału i gwarantują jego istnieniu $\left(e^{m t}\right)$, a tempo wzrostu zostaje wyznaczone przez stałą $p$.

Odpowiednie przygotowanie organizmu jest warunkiem koniecznym do ujawnienia się i rozwijania umiejętności wrodzonych, zdolności i możliwości podczas nauki oraz w czasie pracy. Początkowo kapitał ludzki kształtują nakłady finansowe ponoszone przez rodziców i społeczeństwo. Kapitał ludzki staje się własnością osoby, na rzecz której ponoszone były wspomniane wcześniej nakłady finansowe. Zatem otrzymujemy formułę personalnego kapitału pracownika, który będzie uzależniony od nakładów początkowych $\left(H_{0}\right)$, stałej ekonomicznej $(p)$ i czasu kapitalizacji $(t)$. Wykorzystując ogólny model kapitału, przy założeniu, że $s=m$, otrzymujemy ogólną formułę kapitału ludzkiego:

$$
H_{t}=H_{0} e^{p t}
$$

Formuła (2) przedstawia znaczenie stałej potencjalnego wzrostu w rachunku kapitału ludzkiego. Należy zauważyć, że zmienna $\left(H_{0}\right)$ nie jest nakładem jednorazowym, ale strumieniem nakładów (koszty utrzymania, koszty profesjonalnej edukacji) (Dobija, 2010, s. 77).

Kapitał ludzki oznaczony mianem źródeł finansowania zasobów ludzkich może być zaprezentowany w postaci następującej formuły (Dobija, 2002a):

$$
H_{t}(\mathrm{~T}, \mathrm{p})=\left(K_{t}+E_{t}\right) \times(1+Q(T))
$$

gdzie: czynnik doświadczenia $(Q(T))$, czyli wskaźnik przyrostu kapitału ludzkiego w trakcie pracy, wyraża się funkcją lat (Dobija, 2002b):

$$
Q(T)=1-T^{\frac{\ln (1-w)}{\ln 2}}
$$

gdzie: $w$ - współczynnik uczenia; T - lata pracy zawodowej, T $>1$.

Parametr uczenia $w$ ma wpływ na wzrost doświadczenia. Gdy jest on na przykład równy 0,07 , sugeruje, że dany pracownik będzie wykonywał tę samą pracę w kolejnym roku o 7\% łatwiej, taniej i krócej. 
Tabela 1 przedstawia wzory, które obrazują powstanie kapitału ludzkiego z kosztów utrzymania i kosztów profesjonalnej edukacji:

Tabela 1. Formuły przedstawiające powstawanie kapitału ludzkiego

\begin{tabular}{|l|c|c|}
\hline & Koszty utrzymania & Koszty edukacji \\
\hline Kapitalizacja roczna & $K_{t}=k \times 12 \frac{(1+p)^{t}-1}{p}$ & $E_{t}=e \times 12 \frac{(1+p)^{t}-1}{p}$ \\
\hline Kapitalizacja ciągła & $K_{t}=k \times 12 \frac{e^{p t}-1}{p}$ & $E_{t}=e \times 12 \frac{e^{p t}-1}{p}$ \\
\hline
\end{tabular}

Źródło: (Oliwkiewicz, 2016, s. 484).

gdzie: $H_{t}(T, p)$ - wartość kapitału ludzkiego, $K_{t}$ - skapitalizowane koszty utrzymania, $\mathrm{E}_{t}$ - skapitalizowane koszty profesjonalnej edukacji.

Wykorzystując (formuła (3)) można obliczyć wartość kapitału ludzkiego każdego pracownika, na każdym etapie jego pracy zawodowej, a otrzymane wyniki mogą być podstawą do oszacowania ich należnego wynagrodzenia godziwego.

\section{HISTORIA POLSKIEJ PŁACY MINIMALNEJ}

Na temat płacy minimalnej istnieje wiele opinii i poglądów, które się wzajemnie wykluczają. $Z$ jednej strony przeciwnicy uważają, że istnienie płacy minimalnej to zło konieczne i twierdzą, że powinna funkcjonować na jak najniższym poziomie. Natomiast Międzynarodowa Organizacja Pracy radzi, aby płaca minimalna kształtowała się na poziomie $50 \%$ średniego wynagrodzenia. Komitet Niezależnych Ekspertów Rady Europy powołany przez Radę Europy przedstawia jeszcze inne rozwiązanie dotyczące kształtowania się płacy minimalnej. Bazą do określenia płacy minimalnej ma być płaca przeciętna. Eksperci twierdzą, że wynagrodzenie godziwe powinno kształtować się na poziomie $68 \%$ kwoty tzw. mediany płacowej w danym kraju.

Polska płaca minimalna została wprowadzona po raz pierwszy w 1956 roku. Jej rola w systemie płac w ciągu lat uległa licznym zmianom. Jednak zawsze jest i była to kategoria określająca minimalny gwarantowany przez państwo poziom wynagrodzenia za pracę. Do 1977 roku minimalna płaca stanowiła zagwarantowany wszystkim pracownikom poziom łącznego uposażenia. W kolejnych latach 1977 - 1981 poziom minimalnego wynagrodzenia był wykorzystywany głównie do tworzenia tabel stawek wynagrodzenia i ustalany był jako najmniejsza stawka wynagrodzenia zasadniczego w najniższej kategorii zaszeregowania. W latach 1982-1986 wyznaczano poziom najniższego wynagrodzenia oraz wysokość najniższej stawki wynagrodzenia w najniższej kategorii zaszeregowania. 
Począwszy od lipca 1986 roku, przez kolejne cztery lata, wynagrodzenie najniższe stanowiło jednocześnie najniższą stawkę wynagrodzenia zasadniczego w najniższej kategorii zaszeregowania. W 1990 roku ustalano najniższe wynagrodzenie jako kwotę pełnego miesięcznego wynagrodzenia gwarantowanego pracownikom bez względu na posiadane przez nich kwalifikacje, jak również niezależnie od liczby i rodzaju stosowanych w zakładach pracy elementów wynagrodzenia. Do 1990 roku poziom najniższego wynagrodzenia ustalany był przez Radę Ministrów w drodze uchwały. Od 1990 roku o wysokości najniższego wynagrodzenia stanowiły zarządzenia ministra pracy i polityki socjalnej. W latach 1998-2002 wysokość minimalnego wynagrodzenia określany był w rozporządzeniach ministra pracy, aż do dnia 10 października 2002 roku, kiedy wprowadzona została ustawa o minimalnym wynagrodzeniu za pracę (Raczkowska, 2007, s. 42).

Tabela 2. Minimalne wynagrodzenie za pracę w Polsce w latach 1956-1995

\begin{tabular}{|c|c|c|c|}
\hline Rok & $\begin{array}{c}\text { Wysokość minimalnego } \\
\text { wynagrodzenia (PLZ/PLN) }\end{array}$ & Rok & $\begin{array}{c}\text { Wysokość minimalnego } \\
\text { wynagrodzenia (PLZ/PLN) }\end{array}$ \\
\hline 1956 & $364-500$ & 1982 & $3000-5400$ \\
\hline 1959 & 600 & 1986 & 5400 \\
\hline 1961 & 700 & 1987 & 7000 \\
\hline 1963 & 750 & 1988 & 9000 \\
\hline 1966 & 850 & 1989 & $17800-38000$ \\
\hline 1970 & 1000 & 1990 & $55000-440000$ \\
\hline 1974 & 1200 & 1991 & $875000-1350000$ \\
\hline 1977 & 1400 & 1992 & $1500000-1750000$ \\
\hline 1978 & 1600 & 1993 & $1950000-2400000$ \\
\hline 1979 & 1800 & 1994 & $260-305^{*}$ \\
\hline 1980 & 2000 & 1995 & \\
\hline
\end{tabular}

* zgodnie z ustawą z dnia 7 lipca 1994 r. o denominacji złotego (Dz.U. z 1994 r., nr 94, poz. 84 z późn. zm.) od 1 stycznia 1995 r. obowiązuje nowa jednostka pieniężna o nazwie ,złoty” (PLN); 1 PLN = 10000 PLZ.

Źródło: opracowanie własne na podstawie danych z roczników statystycznych GUS.

Tabele 2 i 3 przedstawiają polskie minimalne wynagrodzenie za pracę od początku jego istnienia aż po współczesność. W tabeli 2 przedstawiona jest płaca minimalna za okres 1956-1995. W niektórych latach minimalne wynagrodzenie zmieniało się kilkakrotnie, stąd przedziały od najniższego w danym roku do najwyższego wynagrodzenia minimalnego.

Tabela 3 przedstawia płace minimalne w Polsce w okresie po denominacji złotego, od 1995 roku aż po rok bieżący. 
Historia polskiej płacy minimalnej na gruncie teorii pomiaru kapitału...

Tabela 3. Minimalne wynagrodzenie za pracę w Polsce w latach 1996-2018

\begin{tabular}{|c|c|c|c|}
\hline Rok & $\begin{array}{c}\text { Wysokość minimalnego } \\
\text { wynagrodzenia (PLN) }\end{array}$ & Rok & $\begin{array}{c}\text { Wysokość minimalnego } \\
\text { wynagrodzenia (PLN) }\end{array}$ \\
\hline 1996 & $325-370$ & 2008 & 1126 \\
\hline 1997 & $391-450$ & 2009 & 1276 \\
\hline 1998 & 500 & 2010 & 1317 \\
\hline 1999 & $528-670$ & 2011 & 1386 \\
\hline 2000 & 700 & 2012 & 1500 \\
\hline 2001 & 760 & 2013 & 1600 \\
\hline 2003 & 800 & 2014 & 1680 \\
\hline 2004 & 824 & 2015 & 1750 \\
\hline 2005 & 849 & 2016 & 1850 \\
\hline 2006 & 899,10 & 2017 & 2000 \\
\hline 2007 & 936 & 2018 & 2100 \\
\hline
\end{tabular}

Źródło: opracowanie własne na podstawie danych z roczników statystycznych GUS.

Współczesny polski system płacy minimalnej działa według ustawy z dnia 10 października 2002 r. o minimalnym wynagrodzeniu za płacę (Ustawa, 2002). W myśl przepisów poziom płacy minimalnej to efekt negocjacji partnerów społecznych w ramach Komisji Trójstronnej. Komisja ma obowiązek ogłoszenia stawki płacy minimalnej na najbliższy rok kalendarzowy do dnia 15 lipca roku poprzedniego. Jeżeli termin ten nie zostanie zachowany, decyzja o wynagrodzeniu minimalnym zostaje podjęta przez Radę Ministrów. Ogłoszenie decyzji o najniższym wynagrodzeniu musi nastąpić do dnia 15 września. Ustawa mówi, że płaca minimalna powinna zostać zwiększona o nie mniej niż prognozowany wskaźnik cen na dany rok. Dodatkowo, w sytuacji, kiedy płaca minimalna nie przekracza $50 \%$ średniej krajowej, najniższe uposażenie należy powiększyć o $2 / 3$ przewidywanej dynamiki PKB. Przy ustalaniu poziomu płacy minimalnej powinno się również brać pod uwagę sytuację budżetową, poziom bezrobocia, produktywność pracy oraz potencjał przedsiębiorstw, a także koszty utrzymania.

W Polsce system płacy minimalnej posiada trwałe podstawy prawne, ale raczej jest zachowawczy i ostrożny. Analizując dane dotyczące relacji płacy minimalnej do płacy średniej w Polsce w latach 2008-2017, zawarte w tabeli 4, zauważyć można, że począwszy od 2008r. relacja ta zwiększa się, jednak poziom jej nie spełnia zaleceń MOP i świadczy raczej o utrzymaniu status quo niż dążenie do godziwego poziomu minimalnego wynagrodzenia. W latach 2009-2011 stosunek minimalnego wynagrodzenia do średniego uległ zmniejszeniu. Począwszy od 2012 roku zauważyć można tendencję wzrostową, a w 2017 roku stosunek ten wynosił prawie $47 \%$. Słabym punktem polskiego systemu płacy minimalnej jest jednolita stawka, co powoduje ograniczenia obszaru jej bezpośredniego oddziaływania w kierunku najsłabszych grup zawodowych. 
Tabela 4. Relacja płacy minimalnej do płacy średniej w Polsce w latach 2008-2017

\begin{tabular}{|c|c|c|c|}
\hline Rok & $\begin{array}{c}\text { Minimalne wynagrodzenie } \\
\text { brutto (zł) }\end{array}$ & $\begin{array}{c}\text { Przeciętne wynagrodzenie } \\
\text { brutto w gospodarce } \\
\text { narodowej (zł) }\end{array}$ & $\begin{array}{c}\text { Relacja wynagrodzenia } \\
\text { minimalnego do } \\
\text { wynagrodzenia przeciętnego }\end{array}$ \\
\hline 2008 & 1126 & 2944 & $38,25 \%$ \\
\hline 2009 & 1276 & 3103 & $41,12 \%$ \\
\hline 2010 & 1317 & 3225 & $40,84 \%$ \\
\hline 2011 & 1386 & 3400 & $40,76 \%$ \\
\hline 2012 & 1500 & 3521 & $42,60 \%$ \\
\hline 2013 & 1600 & 3650 & $43,84 \%$ \\
\hline 2014 & 1680 & 3783 & $44,41 \%$ \\
\hline 2015 & 1750 & 3900 & $44,87 \%$ \\
\hline 2016 & 1850 & 4047 & $45,71 \%$ \\
\hline 2017 & 2000 & 4272 & $46,82 \%$ \\
\hline
\end{tabular}

Źródło: opracowanie własne na podstawie danych z roczników statystycznych GUS.

\section{POLSKA PŁACA MINIMALNA A PŁACA GODZIWA}

Szacowanie poziomu godziwych płac minimalnych pracowników zostało przeprowadzone przy wykorzystaniu rachunku pomiaru kapitał ludzkiego. Do modelu zostały przyjęte założenia odnoszące się do sytuacji ekonomicznej w Polsce w danym okresie. Wielkość kosztów utrzymania oparto na rozmiarze kategorii minimum socjalnego publikowanego corocznie przez Instytut Pracy i Spraw Socjalnych. Minimum socjalne to kategoria, która przedstawia wielkość kosztów utrzymania niezamożnych gospodarstw domowych ustalonych na poziomie zabezpieczającym warunki, by w każdym momencie rozwoju człowieka umożliwić reprodukcję jego sił witalnych, posiadanie i wychowywanie dzieci oraz utrzymania więzi ze społeczeństwem (Kurowski, 2002). Należy także zwrócić uwagę na to, że koszty te powinny być liczone jako koszt utrzymania jednej osoby w modelowej 4-osobowej rodzinie pracowniczej (warunek konieczny, by kapitał ludzki mógł zostać odtworzony w długim okresie). Zatem koszty utrzymania na poziomie minimum socjalnego w 2017 roku wyniosły 908,62 zł miesięcznie (Kurowski, 2018).

W Polsce obowiązek szkolny trwa do 18. roku życia, zatem modelowy pracownik, któremu zostanie ustalona płaca godziwa, będzie posiadał wykształcenie podstawowe i nie będzie miał doświadczenia zawodowego, a jego kapitał ludzki będą tworzyły tylko skapitalizowane koszty utrzymania.

Płaca godziwa w myśl teorii pomiaru kapitału ludzkiego wyznacza stała ekonomiczna potencjalnego wzrostu $p=8 \%$, zatem formuła na wynagrodzenie godziwe przedstawia się następująco: 


$$
W=H(T) \times p
$$

gdzie:

$$
H(T)=K
$$

gdzie: $W$ - płaca zasadnicza; $H(T)$ - wartość kapitału ludzkiego (dla pracownika bez wykształcenia i doświadczenia $H(T)=K), p$ - stała ekonomiczna potencjalnego wzrostu.

Obliczenie wartość kapitału ludzkiego i minimalnej płacy godziwej dla pracownika rozpoczynającego pracę zawodową w wieku 18 lat $\mathrm{z}$ wykształceniem podstawowym:

Skapitalizowane koszty utrzymania:

$$
K_{t}=k \times 12 \frac{e^{p t}-1}{p}
$$

Koszty utrzymania kapitalizowane są przez okres 18 lat, zatem:

$$
K_{18}=908 \times 12 \times \frac{e^{0,08 \times 18}-1}{0,08}=438658,77 \mathrm{zł}
$$

Kapitał ludzki 18-letniego pracownika bez doświadczenia:

$$
\mathrm{H}(0)=438658,77 \mathrm{zl}
$$

Płaca zasadnicza powiększona przez składki płacone przez pracodawcę (koszty pracy) dla $H_{0}$ wyznaczana jest przez stałą ekonomiczną potencjalnego wzrostu $p=0,08$

$$
\mathrm{W}=438658,77 \mathrm{zł} \times 0,08=35092,72 \mathrm{zł}
$$

Wynagrodzenie miesięczne (koszty pracy):

$$
\frac{35092,70 \mathrm{zł}}{12 m-c y}=2924,39 \mathrm{zl}
$$

Wyznaczona kwota 2924,39 zł to kwota wynagrodzenia całkowitego, zatem aby wyliczyć wynagrodzenie brutto należy pomniejszyć tą kwotę o składki zapłacone przez pracodawcę (emerytalne: 9,76\%; rentowe: 6,50\%; wypadkowe: 1,80\%; Fundusz Pracy: 2,45\%; Fundusz Gwarantowanych Świadczeń Pracowniczych: 0,1\%; co daje razem: 20,61\%). Wobec powyższego wynagrodzenie brutto będzie wynosić 2424,67 zł.

Tabela 5 prezentuje wyniki obliczeń zgodności wartości kapitału ludzkiego z wartością polskiej ustawowej płacy minimalnej dla pracownika posiadającego wykształcenie podstawowe na początku swojej pracy zawodowej w latach 2008-2017.

Analizując wyniki badań przedstawionych w tabeli 5 stwierdzić można, iż sytuacja w analizowanym okresie z roku na rok się poprawia. W 2008 roku relacja ta 
kształtowała się na poziomie zaledwie $60 \%$ i z każdym kolejnym rokiem zgodność wzrasta. W 2014 roku było to już $75 \%$, a w roku 2017 relacja ta wynosiła $87 \%$. Niestety wciąż brak zgodności 100-procentowej, co świadczy o tym, że ustawowa płaca minimalna w Polsce nie jest płacą godziwą. Jednak jak wcześniej wspomniano wysokość płacy minimalnej rokrocznie w Polsce ulega podwyższeniu, zatem za kilka lat może będzie można stwierdzić pełną zgodność między płacą godziwą wynikającą $\mathrm{z}$ teorii kapitału ludzkiego a ustawowym wynagrodzeniem minimalnym, czyli będzie można określić polskie ustawowe wynagrodzenie minimalne płacą godziwą.

Tabela 5. Analiza zgodności ustawowej płacy minimalnej z wartością kapitału ludzkiego w Polsce w latach 2008-2017

\begin{tabular}{|c|c|c|c|c|c|}
\hline Wyszczególnienie & 2008 & 2009 & 2010 & 2011 & 2012 \\
\hline $\begin{array}{l}\text { Miesięczne koszty } \\
\text { utrzymania (zł) }\end{array}$ & 685 & 710 & 755 & 805 & 845 \\
\hline $\begin{array}{l}\text { Wartość kapitału ludzkiego } \\
\mathrm{H}(\mathrm{T})\end{array}$ & 330926 & 343004 & 364744 & 388899 & 408223 \\
\hline $\begin{array}{l}\text { Roczne koszty pracy } \\
H(T) \times 8 \%\end{array}$ & 26474 & 27440 & 29180 & 31112 & 32658 \\
\hline Miesięczne koszty pracy (zł) & 2206 & 2287 & 2432 & 2593 & 2721 \\
\hline $\begin{array}{l}\text { Miesięczna płaca minimalna } \\
\text { obowiązująca (zł) }\end{array}$ & 1126 & 1276 & 1317 & 1386 & 1500 \\
\hline $\begin{array}{l}\text { Miesięczne koszty pracy } \\
\text { przy obowiązującej płacy } \\
\text { minimalnej (zł) }\end{array}$ & $\begin{array}{l}1126 \times 1,18 \\
=1329\end{array}$ & $\begin{array}{l}1276 \times 1,18 \\
=1506\end{array}$ & $\begin{array}{c}1317 \times 1,18 \\
=1554\end{array}$ & $\begin{array}{l}1386 \times 1,18 \\
=1635\end{array}$ & $\begin{array}{c}1500 \times 1,18= \\
1770\end{array}$ \\
\hline $\begin{array}{l}\text { Relacja między płacą } \\
\text { rzeczywiście obowiązującą } \\
\text { a płacą wynikającą z wartości } \\
\text { kapitału ludzkiego }\end{array}$ & $60 \%$ & $66 \%$ & $64 \%$ & $63 \%$ & $65 \%$ \\
\hline Wyszczególnienie & 2013 & 2014 & 2015 & 2016 & 2017 \\
\hline $\begin{array}{l}\text { Miesięczne koszty } \\
\text { utrzymania (zł) }\end{array}$ & 862 & 852 & 855 & 872 & 908 \\
\hline $\begin{array}{l}\text { Wartość kapitału ludzkiego } \\
\mathrm{H}(\mathrm{T})\end{array}$ & 416436 & 411605 & 413054 & 421267 & 438659 \\
\hline $\begin{array}{l}\text { Roczne koszty pracy } \\
H(T) \times 8 \%\end{array}$ & 33315 & 32928 & 33044 & 33701 & 35093 \\
\hline Miesięczne koszty pracy (zł) & 2776 & 2744 & 2754 & 2808 & 2924 \\
\hline $\begin{array}{l}\text { Miesięczna płaca minimalna } \\
\text { obowiązująca (zł) }\end{array}$ & 1600 & 1680 & 1750 & 1850 & 2000 \\
\hline $\begin{array}{l}\text { Miesięczne koszty pracy } \\
\text { przy obowiązującej płacy } \\
\text { minimalnej (zł) }\end{array}$ & $\begin{array}{c}1600 \times 1,22 \\
=1952\end{array}$ & $\begin{array}{c}1680 \times 1,22 \\
=2050\end{array}$ & $\begin{array}{c}1750 \times 1,22 \\
=2135\end{array}$ & $\begin{array}{l}1850 \times 1,2061 \\
\quad=2231\end{array}$ & $\begin{array}{c}2000 \times 1,2061 \\
=2412\end{array}$ \\
\hline $\begin{array}{l}\text { Relacja między płacą } \\
\text { rzeczywiście obowiązującą } \\
\text { a płacą wynikającą z wartości } \\
\text { kapitału ludzkiego }\end{array}$ & $70 \%$ & $75 \%$ & $78 \%$ & $80 \%$ & $82 \%$ \\
\hline
\end{tabular}

Źródło: opracowanie własne. 


\section{ZAKOŃCZENIE}

Wynagrodzenie za prace, jak wcześniej wspomniano, to często główne źródło dochodu rodziny. Płaca powinna być taka, aby mogła zaspokoić niezbędne potrzeby pracownika i jego rodziny oraz umożliwić odtworzenie zdolności do pracy. Polska płaca minimalna ma już długą historię jednak w ciągu tych kilkudziesięciu lat istnienia nie spełniała roli godziwej płacy minimalnej. Obliczenia zawarte w tym opracowaniu, dają możliwość zdefiniowania pojęcia godziwego wymiaru płacy, jako kwoty równoważącej koszty rozproszenia i jednocześnie zapewniającej zachowanie wartości kapitału ludzkiego. System płacy minimalnej powinien gwarantować minimalną płacę godziwą, czyli zgodną z wartością kapitału, wszystkim zatrudnionym, a nie tylko najsłabszym grupom. Niestety w Polsce brak takiego systemu, a powyższe obliczenia wskazują jednoznacznie, że polska płaca minimalna nie jest wartością godziwą.

\section{BIBLIOGRAFIA}

Becker, G.S. (1975). Human Capital 2nd ed. New York: National Bureau of Economic Research.

Blaug, M. (1995). Metodologia ekonomii. Warszawa: PWN.

Dobija, M. (2002a). Struktura i koszt kapitału. Zeszyty Naukowe Akademii Ekonomicznej w Krakowie, 562, 59-67.

Dobija, M. (2002b). Kapitał ludzki i intelektualny w aspekcie teorii rachunkowości. Przegląd Organizacji, 1.

Dobija, M. (2009). Fundamentalne przyczyny kryzysów finansowych. Zeszyty Naukowe Małopolskiej Wyższej Szkoły Ekonomicznej, 2 (13), 171-192.

Dobija, M. (red.). (2010). Teoria pomiaru kapitału i zysku. Kraków: Wydawnictwo Uniwersytetu Ekonomicznego w Krakowie.

Dobija, M. (red.). (2011). Kapitał ludzki w perspektywie ekonomiczne. Kraków: Wydawnictwo Uniwersytetu Ekonomicznego w Krakowie.

Dobija, M. (red.). (2014). Teoria rachunkowości podstawa nauk ekonomicznych. Kraków: Wydawnictwo Uniwersytetu Ekonomicznego w Krakowie.

Dobija, M. (2016). Ekonomia pracy, godziwych wynagrodzeń i racjonalnych nierówności - laboryzm. Nierówności Społeczne a Wzrost Gospodarczy, 47 (3/2016), 25-52. DOI: 10.15584/nsawg.2016.3.2

Kozioł, W. (2011). Rozwój rachunku kapitału ludzkiego. W: M. Dobija (red.), Kapitat ludzki w perspektywie ekonomicznej (s. 47-81). Kraków: Wydawnictwo Uniwersytetu Ekonomicznego w Krakowie.

Kurek, B. (2011). Hipoteza deterministycznej premii za ryzyko. Kraków: Wydawnictwo Uniwersytetu Ekonomicznego w Krakowie.

Kurowski, P. (2002). Koszyki minimum socjalnego i minimum egzystencji-dotychczasowe podejście, Instytut Pracy i Spraw Socjalnych, Warszawa. 
Kurowski, P. (2018). Informacja o poziomie minimum socjalnego w 2017 r. (na podstawie danych średniorocznych). Pobrane $\mathrm{z}$ : https://www.ipiss.com.pl/?zaklady=minimum-socjalne (2018.05.31).

Mincer, J. (1962). Labor force participation of married women: a study of labor supply. W: L.H. Greg (ed.), Aspects of labor economics (s. 63-105). Princeton: Princeton University Press.

Oliwkiewicz, B. (2016). Wynagrodzenie godziwe absolwenta studiów wyższych w Polsce w aspekcie modelu kapitału ludzkiego. Nierówności Społeczne a Wzrost Gospodarczy, 47 (3/2016), 481-491. DOI: 10.15584/nsawg.2016.3.35

Renkas, J. (2012). Empiryczny test modelu kapitału ludzkiego i minimalnych wynagrodzeń. Nierówności Społeczne a Wzrost Gospodarczy, 24, 280-291.

Ustawa z dnia 10 października 2002 r. o minimalnym wynagrodzeniu (Dz.U. z 2002 r., nr 200, poz. 1679 ze zm.).

\section{Streszczenie}

Współcześnie wynagrodzenie to jedna z ważniejszych kwestii społeczno-ekonomicznych. To ludzie i ich kapitał tworzą wartość jednostki gospodarczej oraz są źródłem jej sukcesu. Według teorii pomiaru kapitału ludzkiego i godziwych wynagrodzeń, kapitał ludzki to potencjalna zdolność do wykonywania pracy, praca to transfer kapitału do obiektów pracy, a wynagrodzenie to należność za wykonaną pracę zgodnie z jej wartością. Godziwe opłacenie kapitału ludzkiego jest gwarancją jego odtworzenia.

Polska płaca minimalna została wprowadzona po raz pierwszy w 1956 roku. Jej rola w systemie płac w ciągu lat uległa licznym zmianom. Jednak zawsze jest $\mathrm{i}$ była to kategoria określająca minimalny gwarantowany przez państwo poziom wynagrodzenia za pracę. Minimalne wynagrodzenie jest $\mathrm{z}$ jednej strony zabezpieczeniem pracowników przed wyzyskiem ze strony pracodawcy, $\mathrm{z}$ drugiej strony natomiast może być przeszkodą w zwalczaniu bezrobocia.

Artykuł ma na celu przedstawienie historii płacy minimalnej w Polsce od początku jej istnienia oraz zbadanie jej zgodności z wartością kapitału ludzkiego wyznaczoną na podstawie współczesnej teorii pomiaru kapitału ludzkiego i godziwych wynagrodzeń. W pierwszej części opracowania przedstawiona jest historia polskiej płacy minimalnej oraz współczesne poglądy w kwestii kapitału ludzkiego i godziwych wynagrodzeń. W dalszej części, zgodnie z teorią kapitału ludzkiego i godziwych wynagrodzeń, obliczono polską minimalną płacę godziwą oraz zbadano jej zgodność z ustawową płacą minimalną. Do realizacji celu wykorzystano metodę analityczno-opisową. Narzędziem empirycznym służącym weryfikacji były studia literatury przedmiotu oraz studia i analiza danych statystycznych.

Słowa kluczowe: płaca minimalna, kapitał ludzki, płaca godziwa.

\section{The history of the Polish minimum wage based on the theory of measuring human capital and fair remuneration}

\section{Summary}

Nowadays, remuneration is one of the most important socio-economic issues. It is people and their capital that create the value of a business unit and are the source of its success. According to the theory of measuring human capital and decent wages, human capital is a potential ability to work, 
work is a transfer of capital to work objects, and remuneration is a payment for work performed in accordance with its value. Good payment of human capital is a guarantee of its reproduction.

The Polish minimum wage was introduced for the first time in 1956. Its role in the pay system has undergone numerous changes over the years. However, it has always been a category defining the minimum level of remuneration for work guaranteed by the state. The minimum wage is, on the one hand, securing employees against exploitation on the part of the employer, while on the other hand it can be an obstacle to combat unemployment.

The article aims to present the history of the minimum wage in Poland from the beginning of its existence and to examine its compliance with the value of human capital determined on the basis of a contemporary theory of measuring human capital and fair remuneration. The first part of the study presents the history of the Polish minimum wage and contemporary views on human capital and fair remuneration. In the following, in line with the theory of human capital and wages, the Polish minimum wage is calculated and its compliance with the statutory minimum wage is examined. The analytical and descriptive method was used to achieve the goal. The empirical tools used for verification were literature studies and studies and analyses of statistical data.

Keywords: minimum wage, human capital, fair remuneration.

JEL: E24, E 49, J24. 